\title{
Canine Herpesvirus Seroprevalence and Associated Factors in Dogs of Mexico
}

\author{
Edgar Guillermo Valdivia Lara'1, Jesica Ileana Ángeles Solis' ${ }^{1}$, Cesar Cuenca Verde1, \\ Juan Antonio Montaraz Crespo², Laura Cobos Marín³, Juan Carlos Del Río García4, \\ Guillermo Valdivia Anda ${ }^{*}$
}

\begin{abstract}
${ }^{1}$ Laboratorio de Patogenicidad Microbiana, Unidad de Investigación Multidisciplinaria Facultad de Estudios Superiores Cuautitlán, Universidad Nacional Autónoma de México, Cuautitlan Izcalli, México

${ }^{2}$ Laboratorio de Inmunología, Facultad de Estudios Superiores Cuautitlán, Universidad Nacional Autónoma de México, Ciudad de México, México

${ }^{3}$ Facultad de Medicina Veterinaria, Universidad Nacional Autónoma de México Ciudad Universitaria, Ciudad de México, México ${ }^{4}$ Laboratorio de Micotoxinas, Unidad de Investigación Multidisciplinaria, Facultad de Estudios Superiores Cuautitlán, Universidad Nacional Autónoma de México, Ciudad de México, México Email: guillermo897@hotmail.com, jessypezy@hotmail.com,ccuencaverde@hotmail.com, jamc1591@gmail.com, laura.cobosmarin@gmail.com, mcjcrg@gmail.com, *valdivag@unam.mx
\end{abstract}

How to cite this paper: Lara, E.G.V., Solis, J.I.Á., Verde, C.C., Crespo, J.A.M., Marín, L.C., Del Río García, J.C. and Anda, G.V. (2016) Canine Herpesvirus Seroprevalence and Associated Factors in Dogs of Mexico. Open Journal of Veterinary Medicine, 6, 149-162.

http://dx.doi.org/10.4236/ojvm.2016.610019

Received: August 15, 2016

Accepted: October 24, 2016

Published: October 27, 2016

Copyright $\odot 2016$ by authors and Scientific Research Publishing Inc. This work is licensed under the Creative Commons Attribution International License (CC BY 4.0).

http://creativecommons.org/licenses/by/4.0/

\begin{abstract}
Canine herpesvirus (CHV-1) causes disease associated with high mortality in infected puppies, which represents large financial losses for dog breeders. Since CHV-1 at the time of the study he had not been reported in Mexico, the main objective of this study was to determine the prevalence of antibodies against CHV-1 in canine kennels in the metropolitan area of Mexico City. A commercial enzyme-linked immunosorbent assay (ELISA) was used, and the results were compared to those of a viral neutralization test. The ELISA kit uses the complete viral particle as the antigen. The plaque reduction neutralization test was combined with the immunoperoxidase technique because of the low cytopathic effect of CHV-1. Neutralizing antibodies were also detected in 20 randomly selected samples. The prevalence of CHV-1 with ELISA was $87 \%$. The concordance between ELISA and serum neutralization (SN) was 0.1129 , the sensitivity of the ELISA against SN was $1.0(100 \%)$, the positive predictive value was $0.39(39 \%)$, and the negative predictive value was $1(100 \%)$. These results show that ELISA is useful for monitoring the dog population for $\mathrm{CHV}-1$; a positive test result requires confirmation with an SN test, and a negative ELISA result indicates a high probability of being $\mathrm{SN}$-negative. The only variables that were statistically associated with $\mathrm{CHV}-1$ prevalence were breed and kennel. A statistically significant relationship between the degree of ELISA and SN titer was obtained, with a confidence level of $95 \%$. None of the clinical presentation factors was statistically significant. These results suggest that most of the canine population studied in Mexico is in a herpesvirus latency state.
\end{abstract}




\section{Keywords}

Canine Herpesvirus Seroprevalence, Enzyme-Linked Immunosorbent Assay, Serum Neutralization Test

\section{Introduction}

There are currently only one reports of herpesvirus disease in dogs in Mexico, and the disease is not found on any of the lists issued by the International Organization for Animal Health (OIE). However, canine herpesvirus type I (CHV-1) has been isolated in various countries worldwide, and recent studies in Europe suggest that the disease is present in the canine population [1]-[4]. CHV-1 is associated with high mortality in infected puppies, which represents large financial losses for dog breeders. Because of the lack of evidence of its prevalence in Mexico, there are currently no available options for diagnosis, treatment, or prophylaxis of CHV-1 infection. It is considered that the virus is poorly immunogenic, and generates neutralizing antibodies that disappear within only a few months after infection [5].

Recent studies have estimated the worldwide population seroprevalence of $\mathrm{CHV}-1$ at $30 \%-40 \%$, varying according to the country that reports, with a higher prevalence in canine kennels, considering the size of the farm, hygiene, and kennel cough as potential risk factors. A relationship between seroprevalence, history of abortions, and neonatal mortality has also been established [4] [6]. These results have all been based on detection of immunoglobulin G (IgG) antibodies by enzyme-linked immunosorbent assay (ELISA). Furthermore, inhibition of lytic plaques and reduction in fluorescent spots have been employed in the technical serum neutralization $(\mathrm{SN})$ technique has been mainly used for detection of canine herpesvirus and varicella-zoster virus (VZV, belonging to the same viral genus) antibodies [7]-[11]. Canine herpesvirus, like other members of the genus Varicellovirus, usually remains strongly attached to the cell, resulting in very weak cytolytic effects. Two passages of the viral isolates previously obtained in the laboratory [12] were conducted in the chicken embryo by inoculation at the chorioallantoic membrane. This is a widely used technique for replication of other herpesvirus species such as herpes simplex virus (HSV)-1, HSV-2, HSV-3, VZV, laryngotracheitis virus, and pseudorabies [13]. However, to date, there have been no reports of canine herpesvirus replication in the chicken embryo.

The objectives of the present study were to determine the prevalence by the detection of specific IgG antibodies against CHV-1 in canine kennel breeding centers of the metropolitan area of Mexico City, using a commercial ELISA test, to compare the results of ELISA with those of the viral neutralization test, and to determine factors related to the medical history of the animals with the presence of antibodies.

\section{Materials and Methods}

A serological survey was performed in 8 kennels distributed 1 in Mexico City, 3 in the 
State of Mexico, 2 Queretaro and 2 in the city of Guadalajara Jalisco in a period from August 2014 to February 2016. To calculate the required sample size, we adopted previously reported statistical methods [12], the sample size calculation is done considering that the prevalence in the country is unknown and that the objective was to compare two diagnostic tests [13]. A sample size of 96.04 individuals was obtained through this method, and therefore we decided to use 100 dogs. Inclusion criteria were: canines inhabiting the kennel, over 1 year and under 7 years of age, and clinically healthy at the time of sampling, were excluded animals showing any clinical disease, animals less than 1 year and animals in which the medical history of the last 3 months was unaware. Three to five milliliters of Blood was collected without anticoagulant, using Vacutain$\mathrm{er}^{\mathrm{Tm}}$ tubes, from the saphenous or jugular vein in and centrifuged at $1200 \times g$, for $10 \mathrm{~min}$ to room temperature in a clinical centrifuge to obtain serum. The serum was dispensed into Eppendorf tubes and frozen at $-70^{\circ} \mathrm{C}$ until use. The number of animals that were allowed to sample per kennel was: Mexico City (8), 3 in the State of Mexico (13, 32 and 3), Queretaro (11 and 7) and in the city of Guadalajara Jalisco (22 and 4). The Kennels and breeding distribution they are shown in Table 1 . The kennels were selected from the database of customers that counts to particular veterinary diagnostic laboratory, $\mathrm{DIVeT}^{\mathrm{mx}}$, in which there was a history of possible illness, owners were asked for their participation and animals that met the inclusion criteria were sampled randomly. All sampled kennels are breeders breeding pure breeds and often are carried to dog shows on the country.

A survey, questionnaire, was performed during sampling in which the following data were collected: kennel, animal, and history of diseases associated with herpesvirus infection in dogs [4] such as reproductive problems, eye secretions, skin injury, and respiratory secretions.

A commercial ELISA kit (EVL ${ }^{\mathrm{Tm}}$ Woerden, the Netherlands) was used to detect the presence of antibodies against $\mathrm{CHV}-1$. This kit uses the complete viral particle as the antigen. The samples were processed according to the manufacturer recommendations by preparing 1:30, 1:90, 1:270, and 1:810 dilutions of the positive and negative controls and a 1:250 dilution of the serum sample. After the procedure was completed, the absorbance of the wells was read at $450 \mathrm{~nm}$ in a Multiskan Gen, (Thermo Scientific ${ }^{\mathrm{Tm}}$ ) reader. Calculation of the titer was performed based on the results of the absorbance (calculated titer) of each sample, with the assumption that the positive control has a titer of 3600 , as indicated by the manufacturer of the kit (EVL ${ }^{\mathrm{rx}}$ Woerden).

The data were processed using Statgraphics ${ }^{\varpi}$ software, with generalized linear models, taking the calculated titer as the dependent variable and all the following factors as independent variables: age, sex, breed, kennel, weight, height, country of birth, if the dog had copulated or not, the number of litters, and history of respiratory, eye, skin, or reproductive conditions.

Because the virus used_by us at work has a very low cytolytic effect [14], we employ a combination of routine test $\mathrm{SN}$ and observe cytopathic effect of the virus by the detection of cell infection by an immunoperoxidase technique, using antibodies against ca- 
Table 1. Calculated titer of anti-CHV-1 (EVL ${ }^{\mathrm{Tm}}$ ELISA) of animals sampled.

\begin{tabular}{|c|c|c|c|c|c|}
\hline Sample identification & Kennel & Breed & Sex & Age (months) & Calculated titer \\
\hline 001 & 1 & Pug & Female & 39 & ${ }^{\star} 1069.4$ \\
\hline 002 & 1 & Pug & Male & 46 & $\star 295.5$ \\
\hline 003 & 1 & Pug & Female & 14 & $\star 376.1$ \\
\hline 004 & 1 & Pug & Female & 14 & $\star 854.1$ \\
\hline 005 & 1 & Pug & Male & 27 & ${ }^{\star} 1812.3$ \\
\hline 006 & 1 & Pug & Male & 13 & ${ }^{\star} 1492.2$ \\
\hline 007 & 1 & Pug & Female & 58 & *462.2 \\
\hline 008 & 1 & Pug & Female & 51 & $\star 545.0$ \\
\hline 009 & 1 & Pug & Female & 32 & 73.6 \\
\hline 010 & 1 & Pug & Female & 37 & -255.4 \\
\hline 011 & 1 & Pug & Female & 24 & ${ }^{\star} 1000.9$ \\
\hline 012 & 2 & Doberman & Male & 13 & ${ }^{\star} 1120.2$ \\
\hline 013 & 2 & Bulldog & Female & 42 & $\star 760.3$ \\
\hline 014 & 3 & German shepherd & Female & 48 & -204.6 \\
\hline 015 & 3 & German shepherd & Male & 36 & -252.1 \\
\hline 016 & 3 & German shepherd & Female & 72 & -483.9 \\
\hline 017 & 3 & German shepherd & Female & 36 & -382.4 \\
\hline 018 & 3 & German shepherd & Female & 14 & ${ }^{\star} 166.3$ \\
\hline 019 & 3 & Westy & Female & 84 & $\star 2049.7$ \\
\hline 020 & 3 & Westy & Female & 24 & $* 351.8$ \\
\hline 021 & 3 & Westy & Female & 29 & ${ }^{\star} 1864.2$ \\
\hline 022 & 3 & Westy & Female & 24 & $\star 225.9$ \\
\hline 023 & 3 & Westy & Female & 29 & $\star 2748.5$ \\
\hline 024 & 3 & German shepherd & Female & 60 & -336.0 \\
\hline 025 & 6 & Neapolitan mastiff & Female & 48 & $\star 521.8$ \\
\hline 026 & 6 & Neapolitan mastiff & Macho & 45 & *1390.6 \\
\hline 027 & 7 & German shepherd & Female & 39 & $\star 240.3$ \\
\hline 028 & 7 & German shepherd & Female & 30 & $\star 242.5$ \\
\hline 029 & 7 & Westy & Male & 72 & -63.3 \\
\hline 030 & 7 & Westy & Female & 48 & *570.4 \\
\hline 031 & 6 & Neapolitan mastiff & Female & 48 & $\star 2037.6$ \\
\hline 032 & 2 & Great Danes & Female & 18 & *1494.4 \\
\hline 033 & 2 & Great Danes & Female & 30 & $\star 2190.9$ \\
\hline 034 & 3 & German shepherd & Female & 42 & ${ }^{*} 140.2$ \\
\hline 035 & 7 & German shepherd & Male & 72 & $* 337.8$ \\
\hline
\end{tabular}


E. G. V. Lara et al.

\section{Continued}

\begin{tabular}{|c|c|c|c|c|c|}
\hline 036 & 7 & German shepherd & Male & 24 & $* 950.4$ \\
\hline 037 & 7 & German shepherd & Female & 30 & *1996.7 \\
\hline 038 & 4 & Great Danes & Male & 12 & *2083.9 \\
\hline 039 & 4 & Great Dane & Male & 12 & $\star * 963.2$ \\
\hline 040 & 4 & Great Dane & Male & 13 & $\star 221.5$ \\
\hline 041 & 4 & Great Dane & Female & 12 & *1366.6 \\
\hline 042 & 4 & Great Dane & Female & 84 & *1021.4 \\
\hline 043 & 4 & Great Dane & Female & 48 & ${ }^{*} 1956.0$ \\
\hline 044 & 4 & Great Dane & Female & 48 & $\star 3262.7$ \\
\hline 045 & 4 & Great Dane & Male & 60 & $\star 2718.7$ \\
\hline 046 & 5 & Dachshund & Female & 72 & *1200.4 \\
\hline 047 & 5 & Dachshund & Female & 83 & ${ }^{\star} 766.8$ \\
\hline 048 & 5 & Dachshund & Female & 83 & $* 972.5$ \\
\hline 049 & 5 & Dachshund & Male & 36 & $\star * 967.9$ \\
\hline 050 & 5 & Dachshund & Female & 38 & ${ }^{\star} 1449.2$ \\
\hline 051 & 5 & Dachshund & Male & 84 & *452.9 \\
\hline 052 & 5 & Dachshund & Male & 60 & ${ }^{*} 1103.9$ \\
\hline 053 & 5 & Dachshund & Female & 13 & ${ }^{\star} 1306.2$ \\
\hline 054 & 5 & Dachshund & Female & 12 & ${ }^{*} 1355.0$ \\
\hline 055 & 5 & Dachshund & Female & 84 & $\star 2655.9$ \\
\hline 056 & 5 & Dachshund & Female & 38 & ${ }^{\star} 1037.6$ \\
\hline 057 & 5 & Dachshund & Female & 83 & ${ }^{*} 1052.7$ \\
\hline 058 & 5 & Dachshund & Male & 12 & ${ }^{\star} 1530.5$ \\
\hline 059 & 5 & Dachshund & Male & 81 & ${ }^{*} 605.2$ \\
\hline 060 & 5 & Dachshund & Female & 25 & ${ }^{*} 1915.3$ \\
\hline 061 & 5 & Dachshund & Male & 84 & ${ }^{*} 667.9$ \\
\hline 062 & 5 & Dachshund & Female & 36 & ${ }^{*} 1398.0$ \\
\hline 063 & 5 & Dachshund & Male & 82 & ${ }^{\star} 198.3$ \\
\hline 064 & 5 & Dachshund & Male & 48 & ${ }^{*} 264.5$ \\
\hline 065 & 5 & Dachshund & Female & 84 & ${ }^{*} 1670.1$ \\
\hline 066 & 5 & Dachshund & Male & 83 & $\star 2361.8$ \\
\hline 067 & 5 & Doberman & Female & 24 & $* 869.3$ \\
\hline 068 & 5 & Doberman & Female & 25 & ${ }^{\star} 1253.4$ \\
\hline 069 & 5 & Doberman & Male & 80 & ${ }^{\star} 1283.6$ \\
\hline 070 & 5 & Doberman & Female & 12 & ${ }^{\star} 1176.8$ \\
\hline 071 & 5 & Doberman & Male & 13 & $\star 714.9$ \\
\hline 072 & 5 & Doberman & Female & 13 & *886.7 \\
\hline
\end{tabular}


Continued

\begin{tabular}{|c|c|c|c|c|c|}
\hline 073 & 5 & Doberman & Male & 13 & *1276.6 \\
\hline 074 & 5 & Doberman & Male & 13 & $\star 218.2$ \\
\hline 075 & 5 & Golden Retriever & Female & 36 & $\star{ }^{*} 834.5$ \\
\hline 076 & 5 & Doberman & Male & 60 & ${ }^{*} 1333.5$ \\
\hline 077 & 8 & Dachshund & Female & 36 & $\star{ }^{*} 887.8$ \\
\hline 078 & 8 & Dachshund & Female & 12 & $\star{ }^{*} 981.8$ \\
\hline 079 & 8 & Dachshund & Female & 12 & ${ }^{*} 484.0$ \\
\hline 080 & 8 & Dachshund & Male & 14 & ${ }^{\star} 1347.4$ \\
\hline 081 & 8 & Dachshund & Female & 36 & 12.8 \\
\hline 082 & 8 & Dachshund & Female & 12 & ${ }^{\star} 130.0$ \\
\hline 083 & 8 & Dachshund & Male & 36 & $\star 2575.3$ \\
\hline 084 & 8 & Dachshund & Female & 66 & ${ }^{\star} 1786.1$ \\
\hline 085 & 8 & Dachshund & Female & 84 & ${ }^{*} 732.3$ \\
\hline 086 & 8 & Dachshund & Female & 84 & ${ }^{\star} 1807.0$ \\
\hline 087 & 8 & Dachshund & Female & 72 & $\star 3812.5$ \\
\hline 088 & 8 & Golden Retriever & Male & 30 & $\star 550.1$ \\
\hline 089 & 8 & Chihuahua & Female & 60 & -142.8 \\
\hline 090 & 8 & Chihuahua & Female & 84 & 61.5 \\
\hline 091 & 8 & Chihuahua & Female & 16 & $\star 423.6$ \\
\hline 092 & 8 & Chihuahua & Female & 84 & 25.5 \\
\hline 093 & 8 & Dachshund & Female & 12 & ${ }^{\star} 1580.7$ \\
\hline 094 & 8 & Dachshund & Female & 80 & ${ }^{*} 125.3$ \\
\hline 095 & 8 & Dachshund & Male & 48 & ${ }^{*} 651.1$ \\
\hline 096 & 8 & Dachshund & Female & 72 & ${ }^{\star} 880.9$ \\
\hline 097 & 8 & Dachshund & Female & 84 & ${ }^{\star} 1308.0$ \\
\hline 098 & 8 & Dachshund & Male & 12 & ${ }^{\star} 1182.6$ \\
\hline 099 & 5 & Doberman & Female & 48 & ${ }^{\star} 779.9$ \\
\hline 100 & 3 & Chihuahua & Female & 62 & -95.2 \\
\hline
\end{tabular}

*Positive result.

nine herpes virus of dog and anti canine $\operatorname{IgG}$ subsequently antibodies conjugated to peroxidase $\left(\right.$ Sigma $\left.^{\mathrm{Tm}}\right)$ developed by diaminobenzidine $\left(\right.$ Sigma $\left.^{\mathrm{Tm}}\right)$ on wells with cells [7]. Neutralizing antibodies were tested in 20 randomly selected samples

A plaque formation test was used for viral titration. Ten-fold dilutions of the virus isolate $(1: 10,1: 100,1: 1000,1: 10,000)$ were made, and $0.5 \mathrm{ml}$ of each was added to each well of a 12-well NUNC ${ }^{\mathrm{mm}}$ plate containing a monolayer of Madin-Darby canine kidney MDCK cells (In vitro ${ }^{\mathrm{rm}}$, p117) at $90 \%$ confluence in minimal essential medium (MEM) $\left(\right.$ In vitro $\left.^{\mathrm{Tm}}\right)$ with $5 \%$ newborn calf serum (NCS) $\left(\right.$ In vitro $\left.{ }^{\mathrm{Tm}}\right)$. The cells were incubated for 
$1 \mathrm{~h}$ at $35^{\circ} \mathrm{C}$ to allow for viral absorption, with mixing every $15 \mathrm{~min}$. Finally, MEM was added slowly with $1 \%$ newborn calf serum and $0.6 \%$ agarose (Bioline $e^{\mathrm{rm}}$ ) at $45^{\circ} \mathrm{C}$ to allow for solidification, and then incubated at $35^{\circ} \mathrm{C}$ for 3 days. A drop of formaldehyde $\left(\mathrm{JTBaker}^{\mathrm{Tm}}\right)$ was then added to each well so that the agarose could be subsequently removed. The wells were washed carefully with phosphate buffered saline (PBS) and fixed with acetone/methanol $\left(\mathrm{ICR}^{\mathrm{mm}}\right)$ for $10 \mathrm{~min}$. Subsequently, $0.5 \mathrm{ml}$ of a 1:80 dilution of positive anti-CHV-1 control serum $\left(\mathrm{EVL}^{\mathrm{m}}\right)$ was added to each well and incubated for $30 \mathrm{~min}$ at $37^{\circ} \mathrm{C}$. The wells were washed three times with PBS, and anti-canine IgG peroxidase (Sigma Aldrich ${ }^{\mathrm{rx}}$ ) was added and incubated for a further $30 \mathrm{~min}$ at $37^{\circ} \mathrm{C}$. The plate was washed three times with PBS, and a $0.01 \%$ diaminobenzidine solution (Sigma Aldrich ${ }^{\mathrm{Tx}}$ ) with hydrogen peroxide $\left(\mathrm{ICR}^{\mathrm{Tm}}\right)$ was added and held at $15 \mathrm{~min}$ at $37^{\circ} \mathrm{C}$ The plate was washed again with PBS and stained with Harris hematoxylin (Sigma Aldrich $^{\mathrm{Tw}}$ ) for $15 \mathrm{~s}$, and the plates were examined microscopically for the presence of plaque forming units, termed peroxidase-positive spotlights (PPS), which were counted only in wells containing 20 - 100 plaques (Figure 1).

The neutralization assay was performed by incubating equal amounts of virus (50 PPS) with sera at different dilutions (1:4, 1:8, 1:16, 1:32, and 1:64; pretreated for $30 \mathrm{~min}$ at $\left.56^{\circ} \mathrm{C}\right)$ for $30 \mathrm{~min}$ at $37^{\circ} \mathrm{C}$. The mixture $(0.5 \mathrm{ml})$ was inoculated to $\mathrm{NUNC}^{\mathrm{m}}$ plates containing a monolayer of MDCK cells at $90 \%$ confluence. Viral adsorption was allowed for $1 \mathrm{~h}$ at $35^{\circ} \mathrm{C}$, while redistributing the inoculum every $15 \mathrm{~min}$, and MEM supplemented with $1 \%$ calf neonate serum and $0.6 \%$ agarose at $45^{\circ} \mathrm{C}$ was added slowly, allowing for solidification. The plate was incubated at $35^{\circ} \mathrm{C}$ for three days, and then a drop of $40 \%$ formaldehyde was added to each well and the agarose layer was removed the next day. The titer was calculated as the inverse of the highest dilution in which a reduction of at least $50 \%$ of the number of plaques was observed. A serum sample was considered negative if the 1:8 dilution of serum did not show a decrease of $50 \%$ or more in plaque formation.

Simple regression analysis was used to determine the correlation between the results

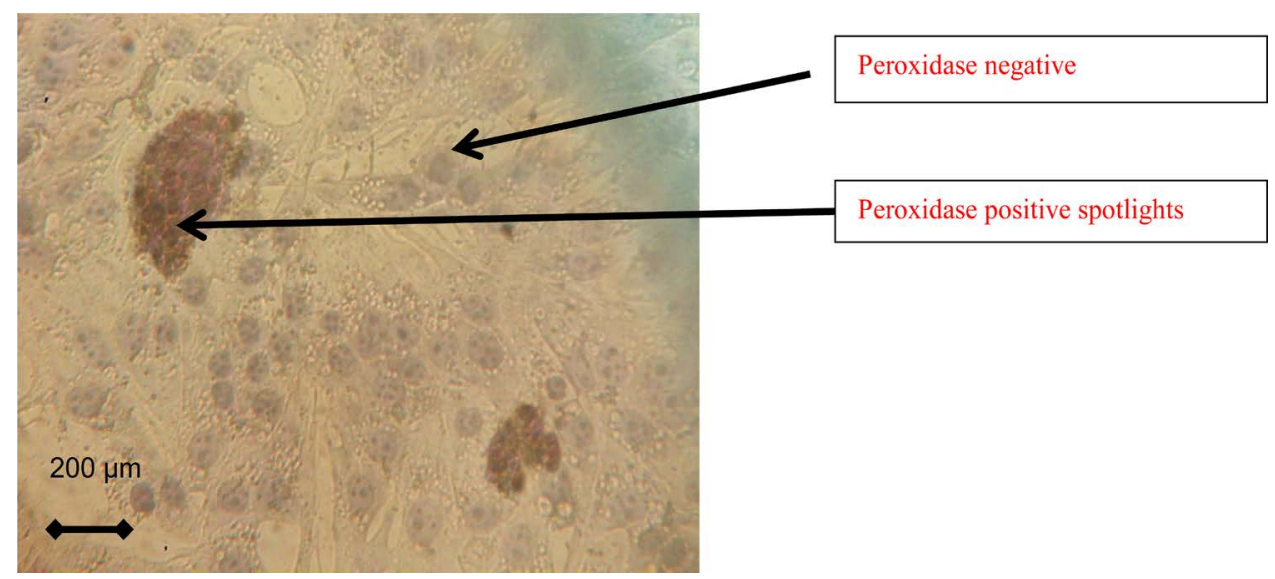

Figure 1. Example of the results taken as positive in the methodology peroxidase positive spotlights (PPS) on cell culture. MDCK cells were infected with canine herpesvirus and incubated for $72 \mathrm{~h}$, and then stained with peroxidase and diaminobenzidine. Magnification, 400x. 
calculated by ELISA and those obtained from the SN test. For the construction of the model, titers under 8 in the SN and an ELISA result $<100$ were considered negative (value of 0 ) according to published by Gerna, and Chambers [7], for Varicella.

\section{Results and Discussion}

The majority of the dogs sampled were females $68 \%$ (68/100); the average age was 35.43 months (2.95 years) the standard deviation was 25.7 . Overall, $86 \%$ of the individuals were born in Mexico, and the remaining 7 were born in the USA (1), Chile (4), Argentina (1), Denmark (1), and Spain (1). Most (85\%) of individuals had never left the country, and $61 \%$ of the sampled animals had mated, with 32 of the 68 females having produced at least one litter. According to the survey, $26 \%$ of the sampled individuals had presented reproductive problems, $14 \%$ had a history of infectious tracheobronchitis, $1 \%$ had eye infections, and $4 \%$ had skin diseases (unrelated to the virus cutaneous presentation). Conventional vaccination schedule was achieved in all the dogs, and none had been previously immunized against $\mathrm{CHV}-1$.

Figure 2 shows the simple linear regression graph of the ELISA results, including the regression equation, slope, and intercept. According to the regression equation, the titer was calculated using the absorbance (Table 1). Some of the calculated titers were negative because of the equation, not the actual observation. Besides, the titles relate to some of the analyzed clinical parameters (Table 2).

According to the personal recommendations of Dr. Van Herwijnen (EVL ${ }^{\mathrm{TM}}$ Woerden, the Netherlands), a result was considered positive if the calculated titer exceeded 100 . Of the 100 samples tested, 87 were positive

The plaque formation test showed a viral titer of $1.72 \times 10^{4} \mathrm{PFU} / \mathrm{ml}$ viral culture. Viral neutralization results were performed for 20 samples from canines selected randomly (Table 3 ). Besides we related to some of the analyzed clinical parameters with ELISA and Serum neutralization test (Table 4).

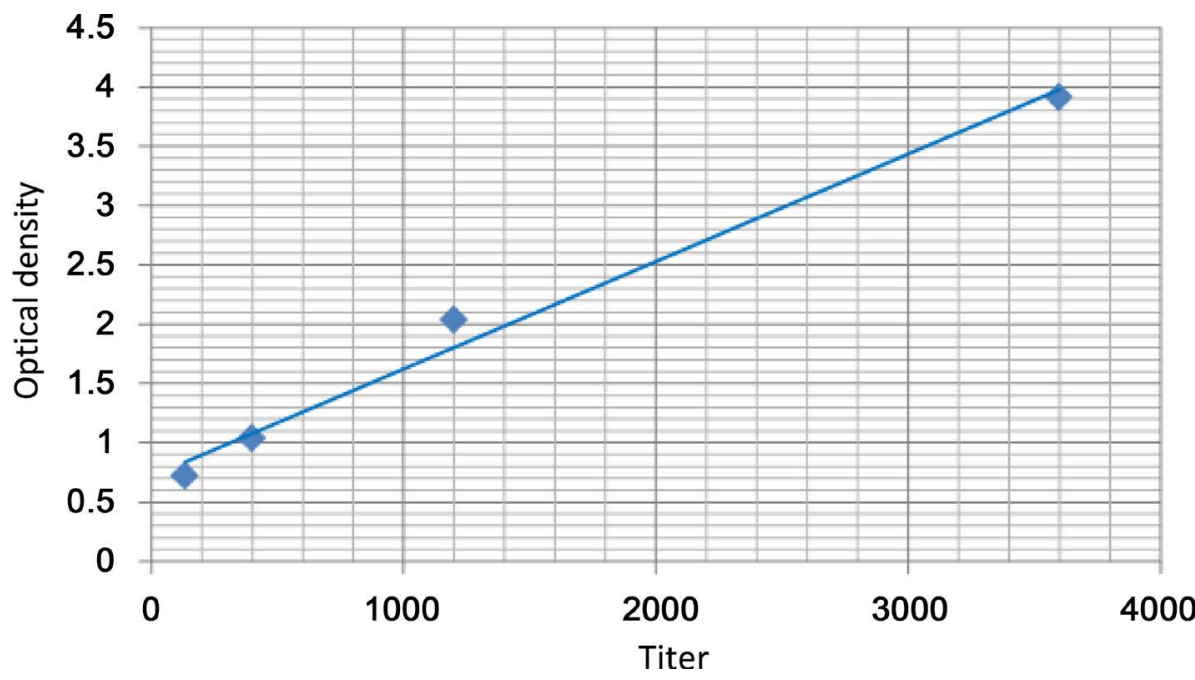

Figure 2. Relationship of the optical density obtained in the ELISA test (EVL ${ }^{\mathrm{rm}}$ Woerden, the Netherlands) with the positive control serum titer: $y=0.0009 x+0.7173 . R^{2}=0.9924$. 
Table 2. Relationship between clinical parameters and results of the ELISA test (EVL ${ }^{\mathrm{Tm}}$ ELISA).

\begin{tabular}{|c|c|c|c|}
\hline Parameter & Variable & Elisa negative & Elisa positive \\
\hline \multirow{8}{*}{ Kennel } & 1 & $2(18.2 \%)$ & $9(81.8 \%)$ \\
\hline & 2 & $0(0 \%)$ & $4(100 \%)$ \\
\hline & 3 & $6(46.2 \%)$ & $7(53.8 \%)$ \\
\hline & 4 & $0(0 \%)$ & $8(100 \%)$ \\
\hline & 5 & $0(0 \%)$ & $32(100 \%)$ \\
\hline & 6 & $0(0 \%)$ & $3(100 \%)$ \\
\hline & 7 & $1(14.3 \%)$ & $6(85.7 \%)$ \\
\hline & 8 & $4(18.2 \%)$ & $18(81.8 \%)$ \\
\hline \multirow[t]{11}{*}{ Breed } & E. Bulldog & $0(0 \%)$ & $1(100 \%)$ \\
\hline & Chihuahua & $4(80 \%)$ & $1(20 \%)$ \\
\hline & G. Retriever & $0(0 \%)$ & $1(100 \%)$ \\
\hline & Dachshund & $1(2.6 \%)$ & $37(97.4 \%)$ \\
\hline & Doberman & $0(0 \%)$ & $11(100 \%)$ \\
\hline & Great Dane & $0(0 \%)$ & $10(100 \%)$ \\
\hline & L. Retriever & $0(0 \%)$ & $1(100 \%)$ \\
\hline & Neapolitan M. & $0(0 \%)$ & $3(100 \%)$ \\
\hline & German Shep. & $5(41.7 \%)$ & $7(58.3 \%)$ \\
\hline & Pug & $2(18.2 \%)$ & $9(81.8 \%)$ \\
\hline & West highland WT & $1(14.3 \%)$ & $6(85.7 \%)$ \\
\hline \multirow[t]{2}{*}{ Sex } & Male & $2(6.3 \%)$ & $30(93.75 \%)$ \\
\hline & Female & $11(16.2 \%)$ & $57(83.8 \%)$ \\
\hline \multirow[t]{2}{*}{ Age } & Young (24 months old or less) & $0(0 \%)$ & $30(100 \%)$ \\
\hline & Adult (more than 24 months old) & $13(18.6 \%)$ & $57(81.4 \%)$ \\
\hline Total & & $13(13 \%)$ & $87(87 \%)$ \\
\hline
\end{tabular}

The results for Simple regression analysis are shown in the Figure 3. The overall concordance between the ELISA and SN results was 0.1129 , which is considered to be low [15], this can be explained, since although both tests measure the levels of antibodies, the detection methods differ. The SN technique detects only neutralizing antibodies that interfere with viral infection directly, whereas the ELISA is unable to distinguish between neutralizing and non-neutralizing antibodies, and therefore has a broader antibody repertoire. In addition, the ELISA detects antibodies that cross reactive with other proteins, as the test used works with the complete virus but only detects IgG antibodies. Moreover, canine herpesvirus is only weakly immunogenic, and antibodies specific to the virus remain at high titers in the blood for only a short window [11] [16]; therefore, the SN assay might fail to detect low levels of antibodies.

The sensitivity of the ELISA test with respect to the SN result was 1 (100\%). In 1989, Takumi et al. [9] developed the indirect ELISA technique, and detected a $26.2 \%$ positivity rate in contrast to a $5 \%$ positive rate obtained by the neutralization technique in 557 dogs. Therefore, ELISA is considered a more sensitive and practical test [17]. Such a 
highly sensitive diagnostic test is useful in clinical settings where the failure to diagnose a disease (i.e., false negative) would create more problems than overdiagnosis (i.e., false positives). This is the case of a screening test, which is performed by applying a diagnostic test that gives valid and reliable results that are inexpensive, easy to perform, and causes minimal discomfort to the patient.

In this study, the positive predictive value was $39 \%$, indicating that a sample that is deemed positive by the ELISA test has only a 39\% chance to be positive by the SN test. This value is relatively low, suggesting that a positive result obtained in a clinical setting or epidemiological study would have to be confirmed by the reference test (SN). Moreover, the negative predictive value was $100 \%$, indicating that if a sample is negative on the ELISA test, it has a $100 \%$ chance to be negative in the reference test (SN). This value indicates that a negative result on ELISA can be considered a true negative with confidence.

In the general linear model, breed and kennel were the only variables statistically as-

Table 3. Serum neutralization results and ELISA titers in 20 randomly selected dogs.

\begin{tabular}{|c|c|c|c|c|c|c|}
\hline $\begin{array}{c}\text { Sample } \\
\text { identification }\end{array}$ & Kennel & Breed & Sex & $\begin{array}{c}\text { Age } \\
\text { (months) }\end{array}$ & $\begin{array}{c}\text { Calculated } \\
\text { titer (ELISA) }\end{array}$ & $\begin{array}{c}\text { Titer (serum } \\
\text { neutralization) }\end{array}$ \\
\hline 002 & 1 & Pug & Male & 46 & 295.5 & 64 \\
\hline 015 & 3 & German shepherd & Male & 36 & -252.1 & $<8$ \\
\hline 016 & 3 & German shepherd & Female & 72 & -483.9 & $<8$ \\
\hline 018 & 3 & German shepherd & Female & 14 & 166.3 & $<8$ \\
\hline 022 & 3 & Westy & Female & 24 & 225.9 & $<8$ \\
\hline 025 & 6 & Neapolitan mastiff & Female & 48 & 521.8 & $<8$ \\
\hline 031 & 6 & Neapolitan mastiff & Female & 48 & 2037.6 & 8 \\
\hline 032 & 2 & Great Dane & Female & 18 & 1494.4 & $<8$ \\
\hline 039 & 4 & Great Dane & Male & 12 & 963.2 & $<8$ \\
\hline 043 & 4 & Great Dane & Female & 48 & 1956.0 & 64 \\
\hline 045 & 4 & Great Dane & Male & 60 & 2718.7 & 32 \\
\hline 048 & 5 & Dachshund & Female & 83 & 972.5 & 16 \\
\hline 051 & 5 & Dachshund & Male & 84 & 452.9 & 32 \\
\hline 063 & 5 & Dachshund & Male & 82 & 198.3 & $<8$ \\
\hline 066 & 5 & Dachshund & Male & 83 & 2361.8 & 64 \\
\hline 071 & 5 & Doberman & Male & 13 & 714.9 & $<8$ \\
\hline 079 & 8 & Dachshund & Female & 12 & 484 & $<8$ \\
\hline 084 & 8 & Dachshund & Female & 66 & 1786.1 & $<8$ \\
\hline 091 & 8 & Chihuahua & Female & 16 & 423.6 & $<8$ \\
\hline 094 & 8 & Dachshund & Female & 80 & 125.3 & $<8$ \\
\hline
\end{tabular}

ELISA titers were calculated and the serum neutralization was scored as the reciprocal of the highest dilution that inhibited $50 \%$ plaque formation. 
Table 4. Agreement between clinical parameters, the ELISA and serum neutralization test.

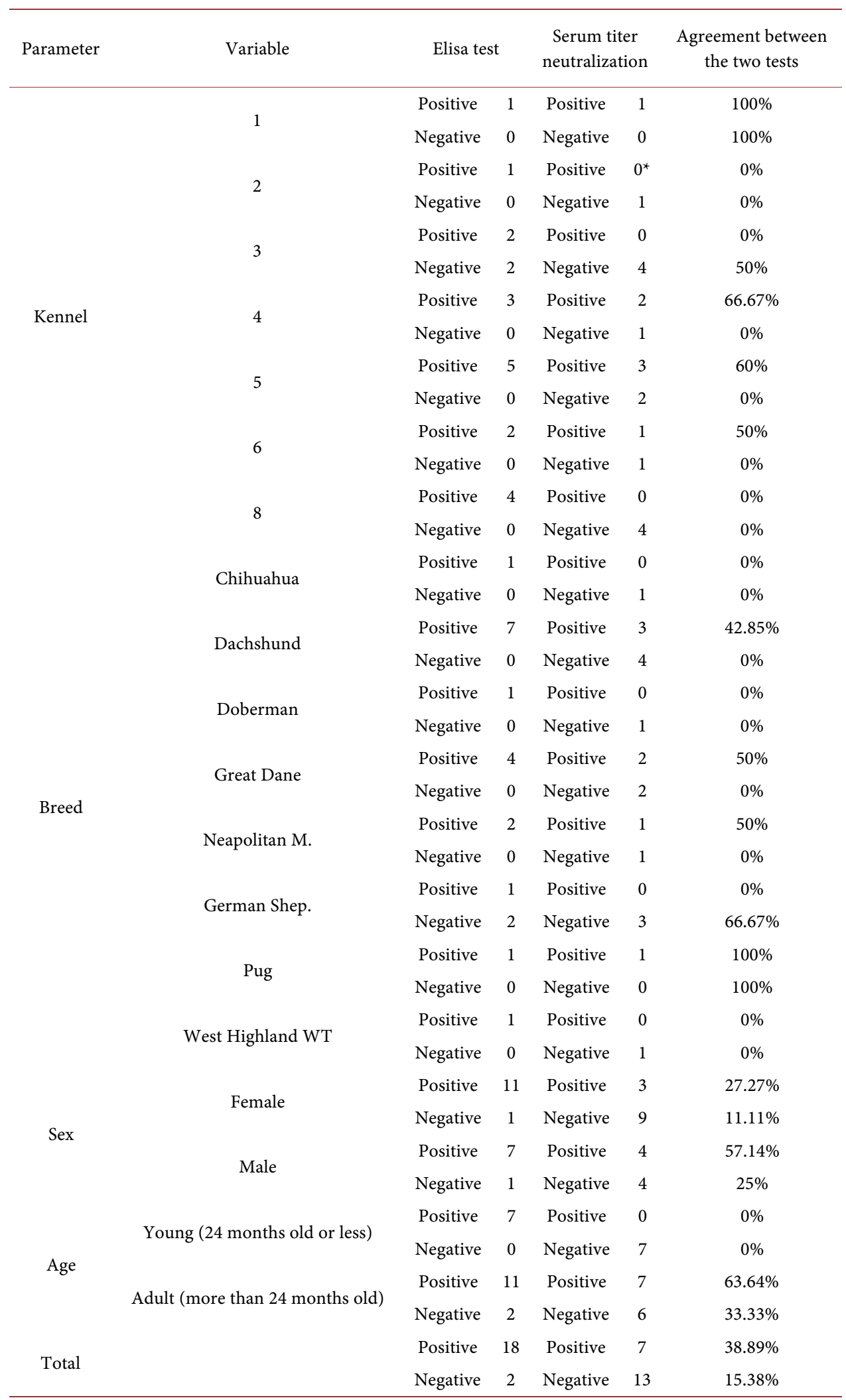

${ }^{*}$ For 100 animals tested by ELISA, only serum neutralization test is performed on 20 randomly selected animals. 


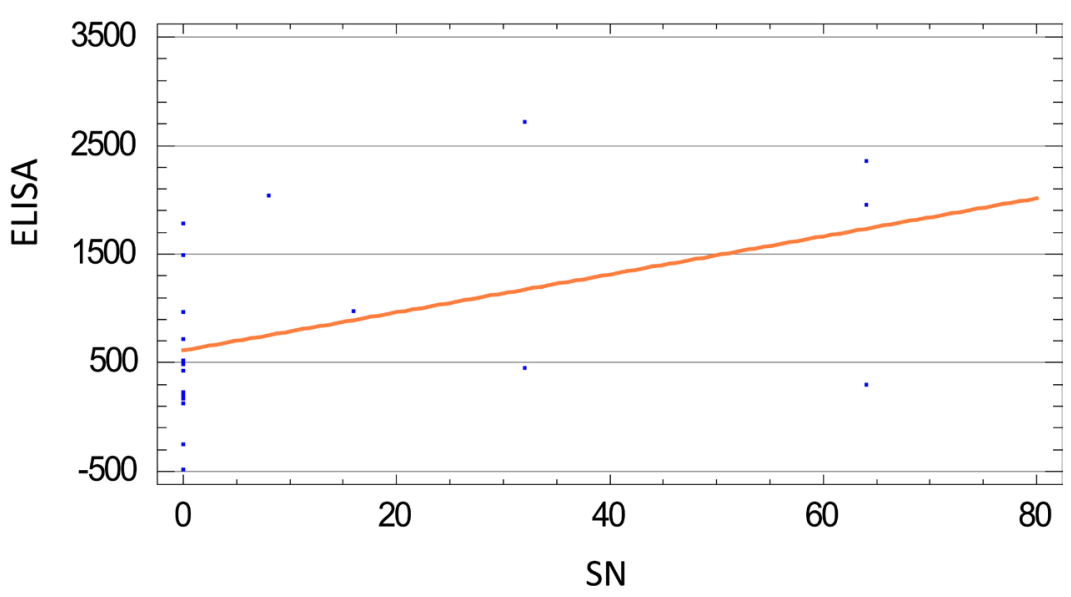

Figure 3. Linear regression of the titers obtained by enzyme-linked immunosorbent assay (ELISA) and the serum neutralization (SN) test. ELISA titers were calculated and SN results were scored as the reciprocal of the highest dilution that inhibited $50 \%$ of plaque formation. $\mathrm{Y}=612.6+$ $17.54 \times \mathrm{X} ; \mathrm{R}^{2}=21.40 \%$.

sociated with the calculated titer, with a p-value of 0.0006 and $\mathrm{R}^{2}$ of 0.3649 , indicating that $36.49 \%$ of the variability in the calculated titer could be explained by these two variables. None of the factors of the clinical presentation such as infectious tracheobronchitis, skin or eye conditions, or reproductive problems had a statistically significant relationship with the serologically calculated titer, which suggests that most of the canine population studied is in viral latency or that the clinical presentations are due to other etiologies [18].

\section{Conclusions and Implications}

The high prevalence of CHV-1 disease in adult dogs in the central area of Mexico is highly significant when considering that in some areas, our previous research [14] showed that puppies from 1 to 3 months of age were killed by infection, and we were able to isolate strains of the virus. Although the litters belonged to different bitches from those sampled in the present study, our results confirm that canine herpesvirus is present in Mexico, causing clinical infection in newborn puppies and is present in latent form in adults, as has been found in other countries. Therefore, Mexico should adopt epidemic control tactics against the disease.

Overall, these results show that the ELISA test is useful for monitoring and screening of the canine population for CHV-1. A positive test result requires confirmation with the SN test, whereas a negative result in ELISA indicates a high probability of being $\mathrm{SN}$-negative, and further confirmation is not required. Therefore, the ELISA test and $\mathrm{SN}$ test developed herein can be used to screen for viruses that have a very low cytolytic effect and are more highly associated with the cells by latency or integration of viral DNA into chromosome cell with or without cell transformation because the literature reports that despite being in viral latency, the body is able to form antibodies against the virus, so it is possible to detect by sensitive tests [16] [17]. This approach is expected to dramatically bring down the cost and time of diagnosis. 


\section{Acknowledgements}

This work was supported by the Project PAPIIT-UNAM IT-202114 "Assessment of canine herpesvirus disease development in Mexico and possible measures for control and prevention".

\section{References}

[1] Lacheretz, A. and Cognard, S. (1998) Epidemiology and Serological Diagnosis of 10 Canine Herpesvirus. Revue de Médecine Vétérinaire, 143, 1477-1488.

[2] Reading, M.J. and Field, H.J. (1998) A Serological Study of Canine Herpesvirus-1 Infection in the English Dog Population. Archives of Virology, 143, 1477-1488. http://dx.doi.org/10.1007/s007050050391

[3] Rijsewijk, F.A.M., Luiten, E.J., Daus, F.J., Van der Heijden, R.W. and Van Oirschot, J. (1999) Prevalence of Antibodies against Canine Herpesvirus 1 in Dogs in the Netherlands in 1997-1998. Veterinary Microbiology, 65, 1-7. http://dx.doi.org/10.1016/S0378-1135(98)00285-5

[4] Ronsse, V., Verstegen, J., Onclin, K., Friederic, F. and Poulet, H. (2004) Risk Factors and Reproductive Disorders Associated with Canine Herpesvirus-1 (CHV-1). Theriogenology, 61, 619-636. http://dx.doi.org/10.1016/S0093-691X(03)00249-8

[5] Greene, C.E. (2012) Canine Herpesvirus Infection. In: Greene, C.E., Ed., Infectious Diseases of the Dog and Cat, 4th Edition, Saunders, Philadelphia, 48-54.

[6] Guigal, P.M., Fontbonne, A., Buff, S., Vincetti, M., Thévenet, F., Pavlowiez, S., et al. (2002) Prevalence of Antibodies against Canine Herpes Virus in French Breeding Kennels. Proceedings of the 3 rd EVSSAR European Congress on Reproduction in Companion, Exotic and Laboratory Animals, Liege, 10-12 May 2002, 132; Cited in Theriogenology, 57.

[7] Gerna, G. and Chambers, R. (1976) Varicella-Zoster Plaque Assay and Plaque Reduction Neutralization Test by the Immunoperoxidase Technique. Journal of Clinical Microbiology, 4, 437-442.

[8] Engels, M., Mayr-Bibrack, B., Ruckstuhl, B. and Metzler, A. (1980) Seroepizootiology of Canine Herpesvirus in Switzerland and Preliminary Trials of a Vaccine. Zentralblatt für Veterinärmedizin Reihe B, 27, 257-267. http://dx.doi.org/10.1111/j.1439-0450.1980.tb01691.x

[9] Takumi A., Kusanagi, K., Tuchiya, K., Xuan, X., Azetaka, M. (1989) Serodiagnosis of Canine Herpesvirus infection-Development of an Enzyme-Linked Immunosorbent Assay and Its Comparison with Two Improved Methods of Serum Neutralization Test. Japanese Journal of Veterinary Science, 52, 241-250. http://dx.doi.org/10.1292/jvms1939.52.241

[10] Xuan, X., Horimoto, T., Limcumpao, J.A., Takumi, A., Tohya, Y., Takahashi, E. and Mikami, T. (1991) Neutralizing Determinants of Canine Herpesvirus as Defined by Monoclonal Antibodies. Archives of Virology, 116, 185-195. http://dx.doi.org/10.1007/BF01319241

[11] Nöthling, J.O., Hössy, D., Steckler, D. and Ackermann, M. (2008) Seroprevalence of Canine Herpesvirus in Breeding Kennels in the Gauteng Province of South Africa. Theriogenology, 69, 276-282. http://dx.doi.org/10.1016/j.theriogenology.2007.09.022

[12] Tilaki, K.H. (2014) Sample Size Estiamation in Diagnostic Test Studies of Biomedical Informatics, Methodological Review. Journal of Biomedical Informatics, 48, 193-204. http://dx.doi.org/10.1016/j.jbi.2014.02.013

[13] Bell, M.L., Pinto, A.T., McKenzie, J.E. and Olivier, J. (2014) A Myriad of Methods: Calculated Simple Size for Two Proportions Was Dependent on the Choice of Simple Size For- 
mula and Software. Journal of Clinical Epidemiology, 67, 601-605.

http://dx.doi.org/10.1016/j.jclinepi.2013.10.008

[14] Valdivia-Lara, E.G., Barrón-Romero, B.L., Cobos-Marín, L., Ángeles-Solis, J.I., GonzálezGallardo S., Cuenca-Verde, C., et al. (2016) Pathology Isolation and Identification of Canine Herpesvirus (CHV-1) in Mexico. Open Journal of Pathology, 6, 111-121.

[15] Watson, P.E. and Petrie, A. (2010) Method Agreement Analysis: A review of Correct Methodology. Theriogenology, 73, 1167-1179.

http://dx.doi.org/10.1016/j.theriogenology.2010.01.003

[16] Carmichael, L.E. (1970) Herpesvirus Canis: Aspects of Pathogenesis and Immune Response. Journal of the American Veterinary Medical Association, 156, 1714-1721.

[17] Ronsse, V., Verstegen, J., Onclin, K., Guiot, A.L., Aeberlé, C. and Nauwynck, H.J. (2002) Seroprevalence of Canine Herpesvirus-1 in the Belgian Dog population in 1997-1998. Reproduction in Domestic Animals, 37, 299-304.

http://dx.doi.org/10.1046/j.1439-0531.2002.00363.x

[18] Carmichael, L.E. and Grene, C.E. (1998) Canine Herpesvirus Infection. In: Greene, C.E., Ed., Infectious Diseases of the Dog and Cat, WB Saunders, Philadelphia, 28-32.

Submit or recommend next manuscript to SCIRP and we will provide best service for you:

Accepting pre-submission inquiries through Email, Facebook, LinkedIn, Twitter, etc. A wide selection of journals (inclusive of 9 subjects, more than 200 journals)

Providing 24-hour high-quality service

User-friendly online submission system

Fair and swift peer-review system

Efficient typesetting and proofreading procedure

Display of the result of downloads and visits, as well as the number of cited articles Maximum dissemination of your research work

Submit your manuscript at: http://papersubmission.scirp.org/

Or contact ojvm@scirp.org 